\title{
EVALUACIÓN DE LA NODULACIÓN Y RENDIMIENTO DEL CULTIVO DE SOJA CON LA APLICACIÓN DE DISTINTAS FORMULACIONES DE INOCULANTES
}

\author{
FORNASERO, L.V. ${ }^{1} \&$ TONIUTTI, M.A. ${ }^{1}$
}

\begin{abstract}
RESUMEN
Se evaluó la aplicación de distintas formulaciones de inoculantes a base de Bradyrhizobium japonicum sobre la nodulación y rendimiento del cultivo de soja en el centro de la provincia de Santa Fe. Los tratamientos fueron: testigo sin inocular, inoculado con B. japonicum, con B. japonicum más factores Nod y con $B$. japonicum más protectores bacterianos. Los patrones de nodulación correspondieron a los de un suelo con buena dotación de población naturalizada de rizobios. El número de nódulos mostró una adecuada nodulación de las plantas, aunque los valores de peso de los nódulos fueron bajos. El tratamiento inoculado más factores Nod presentó un efecto favorable sobre el desarrollo de las raíces. El rendimiento fue superior en los tratamientos inoculados, mostrando incrementos entre un 3,5 \% y un 10,8 \% en relación al testigo. Las plantas de soja inoculadas con $B$. japonicum más factores Nod presentaron los mayores rendimientos. Palabras clave: Inoculantes; factores Nod; protectores bacterianos; soja; nodulación.
\end{abstract}

\section{SUMMARY}

The application of different formulations of Bradyrhizobium japonicum inoculants on nodulation and yield of soybean in the center of the province of Santa Fe was evaluated. The treatments were: uninoculated, inoculated with B. japonicum, with B. japonicum more Nod factors and with $B$. japonicum more bacterial protectors. Nodulation patterns corresponded to a soil with good supply naturalized rhizobia population. The number of nodules showed satisfactory nodulation of the plants, although the weight values of the nodules were low. Treatment inoculated Nod factors presented favorable effect on root development. The yield was higher in inoculated treatments, showing increases between $3.5 \%$ and $10.8 \%$ compared to the control. Soybean plants inoculated with $B$. japonicum more Nod factors showed the highest yields Key words: inoculants, Nod factors, bacterial protectors, soybean, nodulation.

1.- Facultad de Ciencias Agrarias. Universidad Nacional del Litoral. Kreder 2805 (3080) Esperanza, provincia de Santa Fe. e-mail: Ifornase@fca.unl.edu.ar

Manuscrito recibido el 14 de enero de 2015 y aceptado para su publicación el 25 de agosto de 2015. 